\title{
Seabird predation on Arctic cod during summer in the Canadian Arctic
}

\author{
Jordan K. Matley ${ }^{1}$, Aaron T. Fisk ${ }^{2}$, Terry A. Dick ${ }^{1, *}$ \\ ${ }^{1}$ Department of Biological Sciences, University of Manitoba, Winnipeg, Manitoba R3T 2N2, Canada \\ ${ }^{2}$ Great Lakes Institute for Environmental Research, University of Windsor, Windsor, Ontario N9B 3P4, Canada
}

\begin{abstract}
Seabirds feed heavily on Arctic cod Boreogadus saida during the summer in the Canadian Arctic but little is known of the interactions among birds while foraging and the factors that drive feeding behaviour. The objective of this study was to describe the relationship between seabirds and Arctic cod in a productive feeding area distant from breeding colonies. Transect surveys were completed using standardized count protocols to determine the density of seabirds in Allen Bay, Cornwallis Island, Nunavut. Shore-based observation sites determined seabird foraging behaviour associated with the presence of schools and environmental variables. The density of birds (156 birds $\mathrm{km}^{-2}$ ) was high compared to that of other locations in the Canadian Arctic. Several bird species were more active early in the morning and with winds from the south, possibly due to an increase in Arctic cod feeding on zooplankton at the surface. Northern fulmars Fulmarus glacialis and black-legged kittiwakes Rissa tridactyla captured Arctic cod directly from the water; however, they lost nearly $25 \%$ of captures to glaucous gulls Larus hyperboreus and parasitic jaegers Stercorarius parasiticus. These kleptoparasitic seabirds benefited the most in Allen Bay obtaining as much as 8 times more Arctic cod than species capturing cod directly. Northern fulmars captured 3 times more Arctic cod from schools, and black-legged kittiwakes captured similar proportions of schooling and non-schooling cod. We conclude that non-schooling Arctic cod are as important as schooling cod as an energy source for seabirds in nearshore areas, such as Allen Bay, during the summer.
\end{abstract}

KEY WORDS: Boreogadus saida Schooling $\cdot$ Kleptoparasitism · Foraging · Black-legged kittiwake $\cdot$ Northern fulmar $\cdot$ Glaucous gull

\section{INTRODUCTION}

The Canadian Arctic encompasses important marine habitats and productive regions; however, ecological interactions within those areas are poorly understood (Niemi et al. 2010). Specifically, information on foraging behaviour of top predators within the Arctic marine environment is lacking (Reeves \& St. Aubin 2001, Elliott et al. 2008). Understanding foraging decisions of top predators, such as seabirds, is critical because they have important roles in the food web and are indicators of marine ecosystems (Piatt et al. 2007a).
Seabirds use a number of strategies to capture marine prey directly including plunge diving, surface dipping, and pursuit diving underwater. Indirect captures are also important for species that steal food from other individuals. Kleptoparasitism is the act of obtaining food from other individuals through harassment, intimidation, or physical harm. This form of foraging is thought to be an adaptive method to obtain food when resources are limited (Giraldeau \& Caraco 2000). Consequently, many species are opportunistic kleptoparasites, while few species rely mainly on kleptoparasitism to obtain food items (Furness 1987). Kleptoparasitism can be beneficial 
because often less energy is expended compared to capturing prey directly (Stempniewicz \& Iliszko 2010). Nevertheless, little attention has been given to this foraging method in the Canadian High Arctic.

The main prey item for marine seabirds in the Canadian High Arctic is Arctic cod Boreogadus saida as it is an abundant, ubiquitous, and high energy forage fish (Bradstreet et al. 1986). Consuming 12 to 32 individuals is energetically equivalent to $\sim 34500$ calanoid copepods (Bradstreet \& Cross 1982). As such, cod is a keystone species linking lower and higher trophic levels (Welch et al. 1992). Large feeding aggregations including hundreds of whales and seals and thousands of seabirds have been described in relation to cod schools, with the suggestion that such an event could lead to the consumption of $20 \mathrm{t}$ of cod daily (Welch et al. 1993). Arctic cod are spatially and temporally unpredictable and we believe that schooling and non-schooling cod are important components of the Arctic marine food web.

This study describes the relationship between seabirds and Arctic cod in Allen Bay, Cornwallis Island, Nunavut, known for its abundance of cod and predatory interactions during the summer (Welch et al. 1993). The objectives were to (1) determine the density of seabirds in Allen Bay; (2) examine predator activity and feeding behaviour in relation to environmental variables; (3) describe and quantify predatory interactions; and (4) determine the importance of cod schools as food sources. In addition to increasing the knowledge of the behavioural ecology of Arctic species, this study is important to establish the significance of nearshore marine habitats away from breeding colonies as energy sources during the summer.

\section{MATERIALS AND METHODS}

\section{Study area}

Allen Bay is located on the south-western end of Cornwallis Island, Nunavut, in the Lancaster Sound Region $\left(74^{\circ} 43^{\prime} 36.78^{\prime \prime} \mathrm{N}, 95^{\circ} 09^{\prime} 25.23^{\prime \prime} \mathrm{W}\right)$. It is a small $\left(\sim 200 \mathrm{~km}^{2}\right)$ and relatively shallow (rarely $>30 \mathrm{~m}$ ) bay located near the hamlet of Resolute Bay. It is an important area for subsistence hunting of whales and seals. Ice break-up varies annually but in 2010 occurred in early August, although drift ice was continually present throughout the summer. The study area consisted of the southern-most section of the bay $\left(\sim 10 \mathrm{~km}^{2}\right)$ (Fig. 1a). Surveys were conducted between 13 and 31 August 2010 and included observations of black-legged kittiwakes Rissa tridactyla, northern fulmars Fulmarus glacialis, glaucous gulls Larus hyperboreus, parasitic jaegers Stercorarius parasiticus, and Arctic terns Sterna paradisaea.

\section{Density of seabirds}

Parallel transects provided baseline information on seabird density (Fig. 1b). Boat speed was $\sim 10$ to $12 \mathrm{~km} \mathrm{~h}^{-1}$, and 1 observer identified and counted birds. Transect start points were selected randomly. Additional transects were consecutively sampled at $500 \mathrm{~m}$ intervals based on a random selection of travel direction (Fig. 1b). The orientation of transects was selected to avoid bias relating to expected sighting gradients and therefore ran perpendicular from a straight line enclosing the bay (Fig. 1b). The pattern of search was a $90^{\circ}$ arc from bow to side beam using the strip-width method at $150 \mathrm{~m}$ to enumerate seabirds (Fig. 1c). Distance estimates were checked daily with a laser range finder. The survey side (i.e. port or starboard) was selected so that the observer faced the overall direction of travel unless glare from the sun caused sighting difficulty (Fig. 1c). Each transect was divided into $300 \mathrm{~m}$ sections (i.e. 110 s intervals at $10 \mathrm{~km} \mathrm{~h}^{-1}$ ) in which birds flying within the strip (i.e. $300 \mathrm{~m} \times 150 \mathrm{~m}$ ) at the start of the section were instantaneous counts (Tasker et al. 1984). To avoid any effects of the boat on bird behaviour, birds on the water or ice in each section were counted continuously as far ahead as possible (Gould \& Forsell 1989). Birds associating with the boat were not included unless they were seen within the survey section prior to the change in behaviour.

\section{Shore-based observations}

Foraging activity and feeding behaviour were recorded from elevated positions on shore. Sample periods were divided into 4 intervals of $6 \mathrm{~h}$ (00:01-06:00, 06:01-12:00, 12:01-18:00, and 18:01-24:00 h) during $24 \mathrm{~h}$ of daylight. Three locations were randomly sampled for $\sim 4 \mathrm{~h}$ at each interval (i.e. total of $16 \mathrm{~h}$ per location). The following environmental variables were collected because little information is available on direct extrinsic influences on foraging behaviour of seabirds in the High Arctic: wind speed $\left(\mathrm{km} \mathrm{h}^{-1}\right)$, wind direction (deviation from south), tidal state (ebb or flood tide), visibility $(\mathrm{km})$, air temperature $\left({ }^{\circ} \mathrm{C}\right)$, Beaufort scale (an empirical scale to measure wind speed locally using wave action), and presence of ice (estimated percent cover in study area and bay). 

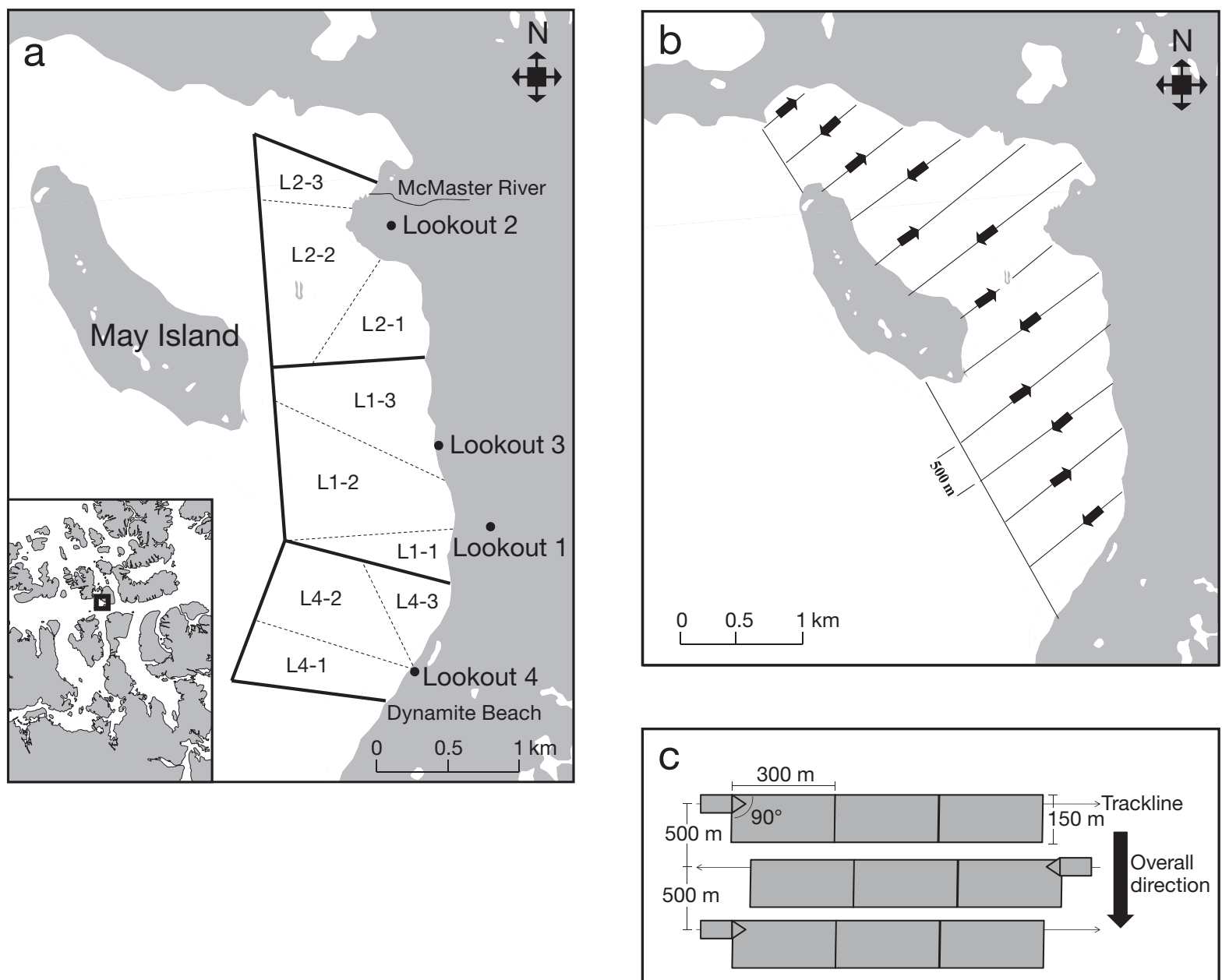

Fig. 1. (a) Study area in Allen Bay, Cornwallis Island, Nunavut ( $74^{\circ} 43^{\prime} 36.78^{\prime \prime}$ N, 95 $99^{\circ}$ '25.23" W) including shore-based observation locations $(\bullet)$. Sample plots for seabird feeding behaviour study are also included (—). Each sample plot (i.e. L1: Lookout 1 ; L2: Lookout 2; L4: Lookout 4) was divided into (----) 3 sections (i.e. 1, 2, 3) using visible landmarks and was alternated randomly after each 5 min sample period. (b) Example of boat route for the survey to determine the density of seabirds. Black arrows show direction of boat travel along tracklines (-). (c) Example of search pattern from bow to side beam during transects using the strip-width method to enumerate seabirds

Four shore-based observation sites were selected (Fig. 1a) based on visibility, access, and heterogeneity of the local marine environment. Lookout 1 $\left(74^{\circ} 43^{\prime} 46.12^{\prime \prime} \mathrm{N}, 95^{\circ} 01^{\prime} 25.79^{\prime \prime} \mathrm{W}\right)$ and $3\left(74^{\circ} 43^{\prime}\right.$ $59.83^{\prime \prime} \mathrm{N}, 95^{\circ} 02^{\prime} 48.45^{\prime \prime} \mathrm{W}$ ) covered a relatively homogeneous area of the bay with depths $>15 \mathrm{~m}$. Lookout $2\left(74^{\circ} 44^{\prime} 55.10^{\prime \prime} \mathrm{N}, 95^{\circ} 03^{\prime} 07.45^{\prime \prime} \mathrm{W}\right)$ covered the area in the vicinity of McMaster River outflow (Fig. 1a). It exhibited the most tidal effects in the study area as small islands were partially or completely submerged at high tide and a shallow shoreline was exposed at low tide. Lookout $4\left(74^{\circ} 43^{\prime} 01.88^{\prime \prime} \mathrm{N}\right.$, $\left.95^{\circ} 03^{\prime} 42.19^{\prime \prime} \mathrm{W}\right)$ referred to Dynamite Shoal, a narrow $(<100 \mathrm{~m})$ shoal usually $<5 \mathrm{~m}$ deep extending from Dynamite Beach where a build-up of thick ice floes was common.

\section{Foraging}

Lookouts 1, 2, and 4 were fixed (Fig. 1a) and sampling plots $\sim 300 \mathrm{~m}^{2}$ adjacent to the shoreline were established based on initial observations that every individual entering the area was visible to the observer. Foraging behaviour was defined as the search for prey (flying and swimming), direct feeding or attempting to feed, and indirect interaction with prey (e.g. kleptoparasitism). Seabirds passing through the grid were counted with the aid of $10 \times$ 15 binoculars in 15 min intervals to avoid multiple counts of the same bird and observer fatigue. Seabirds on ice floes, fast ice and water while in the grid were not counted unless they demonstrated foraging behaviour. 


\section{Feeding behaviour}

Lookouts 2, 3, and 4 were used (Fig. 1a) and sample plots $\sim 1 \mathrm{~km}^{2}$ were created using landmarks on May Island and the adjacent shoreline. Each plot was divided into 3 sections to ensure independent sampling (Fig. 1a). A foraging bird was randomly observed for $5 \mathrm{~min}$ in a section using a 15 to $45 \times 60 \mathrm{~mm}$ spotting scope. As glaucous gulls and parasitic jaegers were less abundant, individual observations were omitted if they could not be located after 1 min. Arctic terns were not included in the analysis of feeding behaviour on cod because they only consumed surface invertebrates. Otherwise, for all species, the first foraging individual was chosen for observation. An individual's time flying, on ice, and on water; feeding attempts; agonistic interactions between birds; and presence of cod schools were recorded. Elevated lookout sites enabled identification of cod schools from a distance. Although rare, if confirmation of a school was not possible (e.g. waves), foraging seabird behaviour was used to discriminate between schooling and non-schooling cod. For example, many birds were attracted to an area when a school was present (cf. Hoffman et al. 1981) and dived repeatedly but if individual birds were feeding on non-schooling cod, other birds were rarely attracted and repeat dives were rare. If the bird was lost or the distance was too far for accurate identification, sampling was terminated. If cod was not seen in the beak when feeding or stealing, the event was considered unsuccessful. Cod was the only fish species captured by seabirds and by gillnetting in Allen Bay during the study, confirming it was the only pelagic fish present.

\section{Analysis of data}

Locations were pooled for feeding as there was no difference for both feeding attempts (Kruskal-Wallis test; $\mathrm{n}=314, \mathrm{p}=0.80$ ) and successful captures (Kruskal-Wallis test; $\mathrm{n}=314, \mathrm{p}=0.58$ ). Principal component analysis (PCA) was used to compare environmental variables (log transformed correlation matrix), seabird activity and feeding (log transformed variance-covariance matrix). Redundancy analysis (RDA) was used to determine the influence of environmental variables on feeding behaviour and foraging activity (log transformed). To avoid multicollinearity, if several variables were strongly associated in the PCA, only one of them was included in the RDA. Visibility was removed from analyses due to a small range throughout the study period. Exploratory linear regressions were completed for the above scenarios prior to ordination techniques in order to reveal the most important variables. For PCA and RDA plots, variables furthest from the origin have greatest discriminatory ability. Variables plotted closely together show a strong positive association and those plotted directly opposite show a strong negative association. Observations for each daily study period were averaged to ensure independent analysis. If there was an extended break ( $>4 \mathrm{~h}$ ) between study periods or the location changed during the same day, observations were grouped separately. Feeding on cod (excluding kleptoparasitism) was assessed with logistic regression (LR) where presence of schools was the dependent variable and feeding success (i.e. from air or water) was the independent variable. The presence of cod schools differed among lookout locations (Kruskal-Wallis test; $\mathrm{n}=309, \mathrm{p}<0.01$ ); however due to a low sample size all locations were pooled. All 5 min sampling periods were analyzed as individual observations (instead of average values) to maximally represent species-specific foraging behaviour and all feeding observations were standardized on a per minute basis. Alpha was set to 0.05 . Ordination analyses were completed using SYN-TAX Ordination 2000. All other analyses were completed using SAS 9.1.

\section{RESULTS}

\section{Density of seabirds}

Forty-four transects $(77.6 \mathrm{~km})$ were completed at an average speed of $10.51 \mathrm{~km} \mathrm{~h}^{-1}$ (Table 1). Northern fulmars and black-legged kittiwakes (hereafter referred to as fulmars and kittiwakes) were the most abundant seabirds while glaucous gulls, parasitic jaegers and Arctic terns had lower densities (Table 1). A total of 1811 birds (5 species) were counted with a density of 156 birds $\mathrm{km}^{-2}$ (Table 1). Kittiwakes were more likely to be on ice while fulmars preferred the water, and glaucous gulls occurred equally on water or flying (Table 1). Iceland gulls Larus glaucoides were rare $(<5 \%)$ in Allen Bay but may have been included in glaucous gull density estimates due to the difficulty discriminating the 2 species.

\section{Foraging}

Foraging activity was recorded over 15 sampling periods and 191 replicates $(47.75 \mathrm{~h})$. Foraging seabirds in the sample grid showed no association with 
Table 1. Fulmarus glacialis, Rissa tridactyla, Larus hyperboreus, Sterna paradisaea, and Stercorarius parasiticus. (a) Survey parameters for this study and two previous ones. (b) Transect survey results for the density (ind. $\mathrm{km}^{-2}$ ) of seabirds in Allen Bay. McKinnon et al. (2009) and Diemer et al. (2010) presented values as abundances and encounter rates, respectively, and density was calculated based on described methods. nd: no data

\begin{tabular}{|c|c|c|c|c|c|c|c|c|c|c|c|c|}
\hline (a) Survey parameters & \multicolumn{4}{|c|}{ This study } & \multicolumn{4}{|c|}{ Diemer et al. (2010) } & \multicolumn{4}{|c|}{ McKinnon et al. (2009) } \\
\hline Date & \multicolumn{4}{|c|}{ 17-28 Aug 2010} & \multicolumn{4}{|c|}{29 Jul-9 Aug 2008} & \multicolumn{4}{|c|}{ 16-21 Sep 2005} \\
\hline No. of transects & & 4 & & & & 3 & 1 & & & 1 & & \\
\hline Total distance $(\mathrm{km})$ & & 77 & & & & 17 & 3.1 & & & 52 & & \\
\hline Area covered $\left(\mathrm{km}^{2}\right)$ & & 11 & & & & 51 & .93 & & & 1 & & \\
\hline Mean speed $\left(\mathrm{km} \mathrm{h}^{-1}\right)$ & & 10 & & & & 15 & -17 & & & 7.4 & -35 & \\
\hline Total no. of birds & & 18 & & & & 9 & 53 & & & 5 & & \\
\hline (b) Density of birds (ind. $\mathrm{km}^{-2}$ ) & $\begin{array}{c}\text { On } \\
\text { water }\end{array}$ & Flying & $\begin{array}{l}\text { On } \\
\text { ice }\end{array}$ & Total & $\begin{array}{c}\text { On } \\
\text { water }\end{array}$ & Flying & $\begin{array}{l}\text { On } \\
\text { ice }\end{array}$ & Total & $\begin{array}{c}\text { On } \\
\text { water }\end{array}$ & Flying & $\begin{array}{l}\text { On } \\
\text { ice }\end{array}$ & Total \\
\hline Northern fulmar & 44 & 14 & 1 & 59 & nd & nd & nd & $<1$ & 1 & 1 & nd & 1 \\
\hline Black-legged kittiwake & 20 & 18 & 29 & 67 & nd & nd & nd & nd & $<1$ & $<1$ & nd & $<1$ \\
\hline Glaucous gull & 10 & 10 & 7 & 27 & nd & nd & nd & 6 & $<1$ & $<1$ & nd & $<1$ \\
\hline Arctic tern & 1 & 3 & 0 & 4 & nd & nd & nd & nd & nd & nd & nd & nd \\
\hline Parasitic jaeger & 0 & $<1$ & $<1$ & $<1$ & nd & nd & nd & nd & nd & nd & nd & nd \\
\hline Total & 75 & 45 & 36 & 156 & nd & nd & nd & 18 & 2 & 2 & nd & 4 \\
\hline
\end{tabular}

each other (Fig. 2a). Fulmars, kittiwakes, and parasitic jaegers were more active in the early morning and with winds from the south (Fig. 2b). Glaucous gulls were positively associated with low wind speed, low Beaufort scale, ebb tide, and high ice in the bay (Fig. 2b). By contrast, Arctic terns were not affected by the environmental variables listed (Fig. 2b).

\section{Feeding behaviour}

Fulmars ( $\mathrm{n}=132 ; 488.5$ min total observation time) and glaucous gulls ( $\mathrm{n}=55 ; 196.5 \mathrm{~min}$ total observation time) flew and rested on water or ice almost equally (Fig. 3a). Kittiwakes ( $\mathrm{n}=100 ; 381.5 \mathrm{~min}$ total observation time) and parasitic jaegers ( $\mathrm{n}=22$; 99.5 min total observation time) spent the majority of foraging time in flight (Fig. 3a). Only fulmars fed on prey other than cod, including zooplankton and food scraps from hunters (cf. Mallory et al. 2010).

Fulmars successfully captured cod 24 and 19\% of the time when diving from air (21 attempts) and the water's surface (32 attempts), respectively (Fig. 3b). The kittiwakes' success rate when plunging from air was 49\% (49 attempts) and did not attempt to feed from the water surface (Fig. 3b). Glaucous gulls successfully fed by plunge diving $(50 \%)$ and dipping from the surface $(100 \%)$, but direct feeding attempts (6) were rare (Fig. 3b). Fulmars, kittiwakes, and glaucous gulls made 0.10, 0.13 , and 0.03 feeding attempts per minute of foraging, respectively. The parasitic jaeger was not observed capturing cod directly.
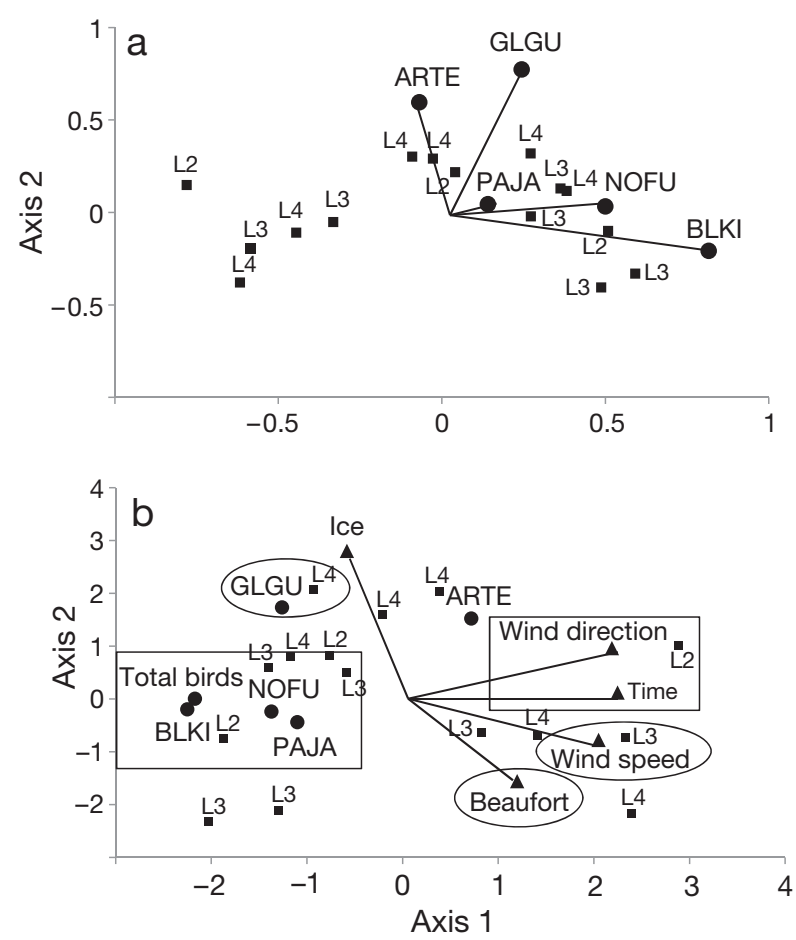

Fig. 2. Sterna paradisaea, Larus hyperboreus, Stercorarius parasiticus, Fulmarus glacialis, and Rissa tridactyla. (a) Principal component analysis (Axis 1: $57.46 \%$, Axis 2: $16.81 \%$ of the total variance) and (b) redundancy analysis (Axis 1: $20.66 \%$, Axis $2: 7.94 \%$ of total activity variance) of seabird activity. ARTE: Arctic tern, GLGU: glaucous gull, PAJA: parasitic jaeger, NOFU: northern fulmar, BLKI: black-legged kittiwake. - - with numbers L1 to L4: lookout sites. Rectangular and oval frames represent associated variables and/or species. Air temperature was positively associated with wind direction in the PCA and was removed to avoid multicollinearity. Similarly, tide and ice (in the bay) were removed as they were associated with wind speed 

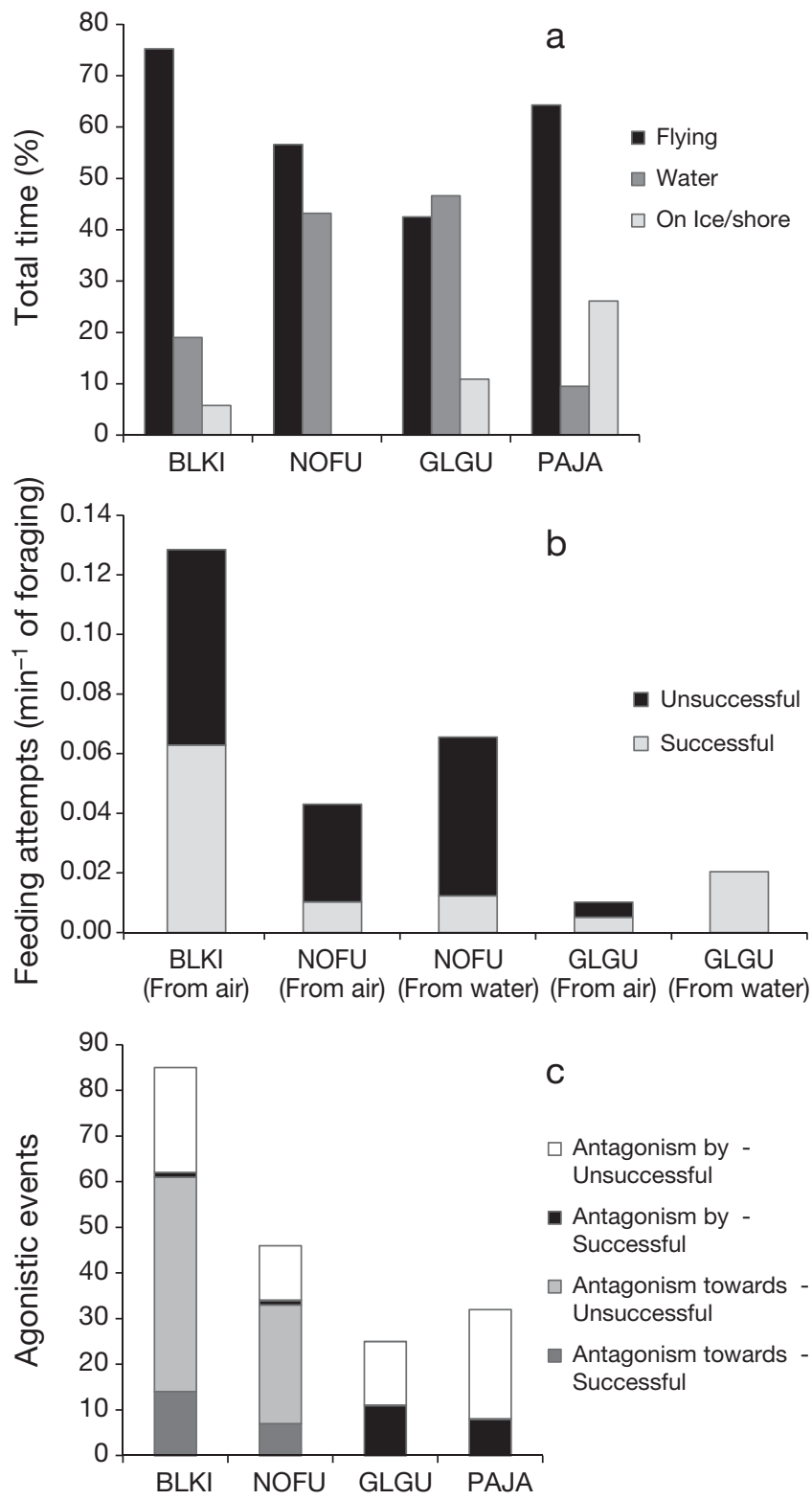

Fig. 3. Larus hyperboreus, Stercorarius parasiticus, Fulmarus glacialis, and Rissa tridactyla. (a) Total time (\%) spent flying, on water, and on ice/shore during the feeding behaviour study. (b) Total number of feeding attempts (successful and unsuccessful) from either plunge dives from the air or dives from the water's surface (standardized $\mathrm{min}^{-1}$ foraging). (c) Total counts of seabird antagonistic interactions (successful and unsuccessful). See Fig. 2 legend for species abbreviations

Fulmars and kittiwakes had $\sim 25 \%$ of captures stolen but stole few cod $(<10 \%$ of cod consumed $)$ from other birds (Fig. 3c). Glaucous gulls and parasitic jaegers successfully stole cod during 44 and $26 \%$ of agonistic interactions, respectively (Fig. 3c). Table 2 lists the net average number of fish caught per hour of foraging.
Table 2. Larus hyperboreus, Stercorarius parasiticus, Fulmarus glacialis, Rissa tridactyla feeding on Boreogadus saida. Net amount of Arctic cod consumed by seabird species determined by dividing the total cod captured directly and lost or gained during antagonistic interactions by the total time observed for each species. See Fig. 2 legend for species abbreviations

\begin{tabular}{|lc|}
\hline Species & No. of cod consumed $\left(\mathrm{h}^{-1}\right.$ foraging $)$ \\
\hline BLKI & 1.73 \\
NOFU & 0.61 \\
GLGU & 4.89 \\
PAJA & 4.82 \\
\hline
\end{tabular}

Fulmars were more successful at capturing cod during periods of lower wind speeds and early (00:01-06:00 h) in the morning (Fig. 4). Later in the day (18:01-24:00 h) there were less successful captures from dives underwater. Higher wind speeds were associated with less captures from air but higher air temperatures and winds from the south were associated with more captures (Fig. 4). Kittiwake feeding was not strongly correlated with environmental variables based on the RDA (Axis 1: $20.99 \%$, Axis 2: $0.34 \%$ of total feeding variance).

Glaucous gulls captured significantly more schooling cod than non-schooling $\operatorname{cod}\left(\mathrm{LR}_{i} \mathrm{n}=60, \chi^{2}=\right.$ 5.50, L (logit for an event) $=-0.79+11.59 x, p=0.02$ ) (Table 3). Fulmars had more feeding attempts (LR; $\mathrm{n}=132, \chi^{2}=4.50, \mathrm{~L}=-0.80+2.89 x, \mathrm{p}=0.03$ ) and were more successful $\left(\mathrm{LR}_{i} \mathrm{n}=132, \chi^{2}=4.22, \mathrm{~L}=\right.$ $-0.73+11.11 x, p=0.04)$ when diving from water (Table 4). Although not statistically significant the following observations are interesting. There were more feeding attempts by all species of birds and greater feeding success when schools of cod were present (Table 3). Also, the mean success rate of capturing schooling and non-schooling cod was similar at 37 and $39 \%$, respectively, for all species of birds. Finally, fulmars captured 3 times more cod from schools (Table 3). A total of 40 cod were captured directly (50\% schooling; $50 \%$ non-schooling) during the feeding behaviour study.

\section{DISCUSSION}

\section{Density of seabirds}

Seabird population data are lacking in much of the Canadian Arctic (Mallory \& Fontaine 2004, Niemi et al. 2010), particularly in locations distant from breeding colonies. Our density estimates of seabirds in Allen Bay were high compared to those from other 
Fig. 4. Fulmarus glacialis. Redundancy analysis (RDA) of northern fulmar success or failure in capturing cod in relation to environmental variables for $15 \mathrm{sam}-$ pling periods (Axis 1: 16.99\%, Axis 2: $11.34 \%$ of total feeding variance). Small squares associated with numbers refer to lookout sites. Rectangles and ovals represent associated variables or species. Beaufort scale was removed to reduce multicollinearity with wind speed. Ice represents the percentage of ice in the study area

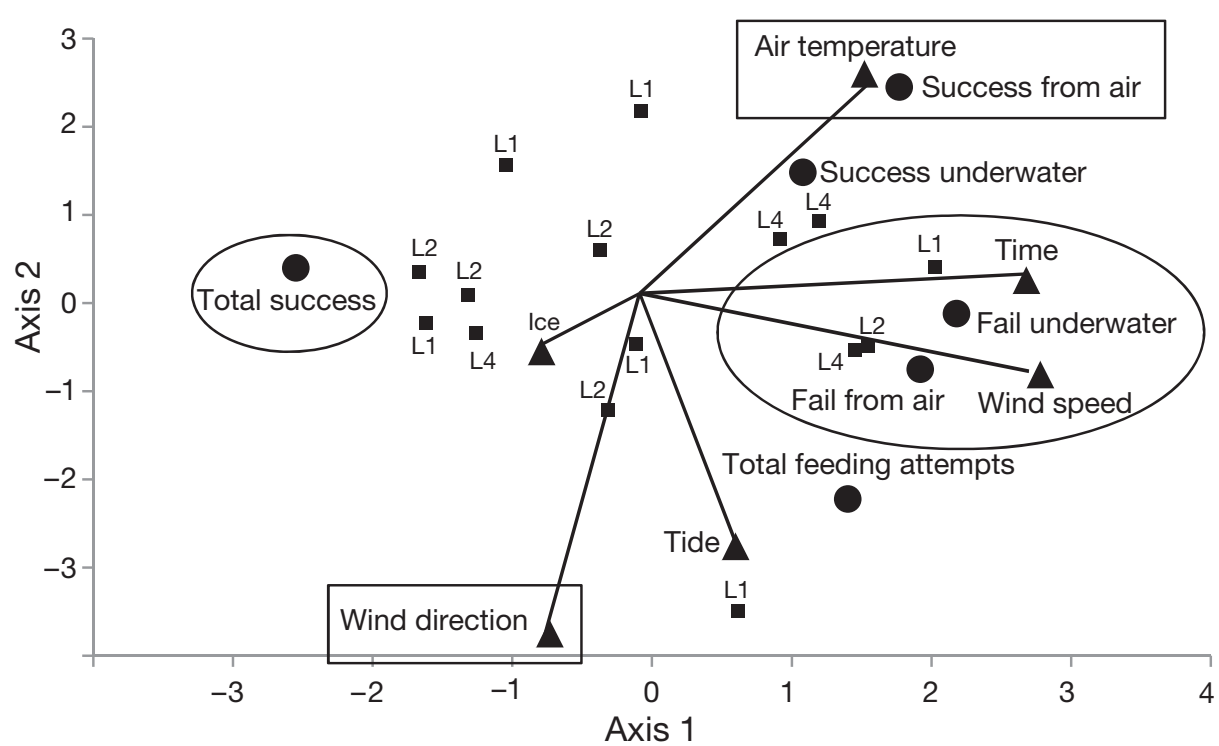

Table 3. Stercorarius parasiticus, Fulmarus glacialis, and Rissa tridactyla feeding on Boreogadus saida. Number of feeding attempts and successful captures of seabird species in relation to schooling and non-schooling Arctic cod. Means \pm SE. Significant p-values are in bold and refer to logistic regression tests. See Fig. 2 legend for species abbreviations

\begin{tabular}{|lccc|}
\hline & Non-schooling & Schooling & $\mathrm{p}$ \\
\hline All species (n= 309) & & & \\
$\begin{array}{l}\text { Feeding attempts } \\
\text { Successful captures }\end{array}$ & $0.08 \pm 0.01$ & $0.11 \pm 0.02$ & 0.16 \\
BLKI (n = 100) & 0.01 & $0.04 \pm 0.01$ & 0.37 \\
$\begin{array}{l}\text { Successful captures } \\
\text { NOFU (n= 132) }\end{array}$ & $0.08 \pm 0.02$ & $0.06 \pm 0.02$ & 0.57 \\
$\begin{array}{l}\text { Successful captures } \\
\text { GLGU (n= 60) }\end{array}$ & $0.01 \pm 0.01$ & $0.03 \pm 0.01$ & 0.07 \\
Successful captures & $0.01 \pm 0.01$ & $0.07 \pm 0.02$ & $\mathbf{0 . 0 2}$ \\
\hline
\end{tabular}

Table 4. Fulmarus glacialis feeding on Boreogadus saida. Number of feeding attempts and successful captures of cod by northern fulmars $(\mathrm{n}=132)$ from plunge dives (from air) and dives from the surface (from water) in relation to schooling and non-schooling Arctic cod. Means \pm SE. Significant pvalues are in bold and refer to logistic regression tests

\begin{tabular}{|lccc|}
\hline & Non-schooling & Schooling & $\mathrm{p}$ \\
\hline Feeding attempts & & & \\
From air & $0.04 \pm 0.01$ & $0.05 \pm 0.02$ & 0.65 \\
From water & $0.04 \pm 0.01$ & $0.10 \pm 0.03$ & $\mathbf{0 . 0 3}$ \\
Successful captures & & & \\
From air & $0.01 \pm 0.01$ & $0.01 \pm 0.01$ & 0.98 \\
From water & $<0.01$ & $0.02 \pm 0.01$ & $\mathbf{0 . 0 4}$ \\
\hline
\end{tabular}

studies in the Canadian Arctic that used similar techniques. McKinnon et al. (2009) reported a density of $3.6 \pm 0.5$ ind. $\mathrm{km}^{-2}$ in early fall in the Northwest Passage (Table 1) and Diemer et al. (2010) reported encounters of 5.5 ind. $\mathrm{km}^{-1}$ (equivalent to 18.4 ind. $\mathrm{km}^{-2}$ ) in Cumberland Sound during the summer (Table 1). Allen Bay is a smaller, more protected area than either the Northwest Passage or Cumberland Sound and has significant concentrations of Arctic cod, fulmars, and kittiwakes during the summer. The nearest breeding colony of fulmars and kittiwakes is $\sim 100$ and $\sim 50 \mathrm{~km}$ away, respectively (Mallory \& Fontaine 2004). This does not appear to be a factor affecting our density estimates since many of the birds using Allen Bay are likely non-breeding or immature individuals (M. Mallory pers. comm.). Perhaps scale affected density estimates but until data are collected from larger concentrated feeding areas we can only speculate on its effect.

\section{Foraging}

Foraging of fulmars, kittiwakes, glaucous gulls and parasitic jaegers was affected by environmental variables such as time of day, wind, tide, and ice. The strong association of fulmar, kittiwake, and parasitic jaeger activity with wind direction from the south may be attributable to an increase in fish movement into the area. For example, strong winds can cause upwelling (Lagadeuc et al. 1997, Carmack \& Macdonald 2002) and zooplankton located within Resolute Passage or the Barrow Strait may be pushed north into Allen Bay, attracting cod. In this study ful- 
mar activity was not positively associated with wind speed but on occasions when winds reached as much as $50 \mathrm{~km} \mathrm{~h}^{-1}$ fulmars were usually the only species in flight. This behaviour is supported by Furness \& Bryant (1996), who suggested that fulmars glide during high wind speeds at sea to reduce field metabolic rates.

Glaucous gull and parasitic jaeger foraging was independent of the species they stole from (Fig. 2a), suggesting their movements were more readily affected by environmental variables (e.g. Bélisle \& Giroux 1995). Both wind speed and Beaufort scale affected glaucous gull activity indicating foraging in strong winds with poor water visibility is not profitable in Allen Bay. Although cod was stolen from species that showed no strong association with tide (Fig. 2b), glaucous gulls may be foraging during ebb tide to maximize the ability to capture prey directly when the water level is lower and prey may be more exposed (e.g. Moore et al. 2008).

\section{Feeding behaviour}

Two basic feeding strategies used by marine birds to capture schooling and non-schooling cod were identified in Allen Bay: direct feeding (diving from air or water, and surface dipping) and indirect feeding (kleptoparasitism). Fulmars are only capable of shallow dives underwater $(<2.6 \mathrm{~m}$ deep) (Garthe \& Furness 2001). They had a higher dive success rate from water when a school was present but capture rates were lower compared to those of the other birds (Table 2). This indicates an inability to pursuit-dive underwater to exploit non-schooling cod. Since fulmars were more likely to successfully feed when the wind speed was low, wave action and visibility at the water surface may reduce their ability to see and capture prey. While fulmars have adaptations to reduce energetic requirements, such as low basal metabolic rate (Birt-Friesen et al. 1989, Bryant \& Furness 1995) and increased lipid metabolism to reduce flight load (Warham 1996), its poor foraging success on cod (e.g. Table 2) likely explains why it was observed consuming organisms other than cod, unlike the other birds. Finally, the higher feeding success by fulmars in the morning (i.e. 00:01-06:00 h) may reflect the presence of cod near the surface feeding (cf. Benoit et al. 2010). Since cod feed on amphipods and calanoids that migrate to the surface at night during late spring (Fortier et al. 2001) and summer (Sameoto 1984), this may make them more vulnerable to shallow diving birds.
Kittiwakes relied exclusively on capturing cod directly by plunge diving from the air and spent little time on the ice or on water while foraging (Fig. 3a). Daunt et al. (2002) calculated that $47 \%$ of time was spent flying during foraging trips (excluding flight from the colony) in the North Sea. Our observations, which selectively chose birds exhibiting foraging behaviour, may account for the higher flying time (i.e. $75 \%$ ). However, kittiwakes use flexible foraging strategies in response to local conditions (Daunt et al. 2002). The high success rates may result in shorter foraging bouts and higher flight time during those bouts. Welcker et al. (2010) reported that kittiwakes did not adjust their metabolic rate in response to environmental variability, suggesting they have little buffering capacity against extrinsic factors and constantly perform close to an energetic ceiling. Perhaps this explains why environmental variables did not strongly influence kittiwake feeding. Even if cod schools were influenced by wind direction and wind speed, kittiwakes were able to forage independently of schools since they feed as efficiently on nonschooling cod. Since schools are patchy and often unpredictable, the ability to exploit non-schooling fish may explain why kittiwakes are typically more piscivorous in other parts of the Arctic compared to fulmars and glaucous gulls (Bradstreet 1976, Hobson 1993). Kittiwakes were the most successful at capturing cod, and it follows that they were also the species most commonly kleptoparasitized. Nevertheless, if we assume a breeding adult requires $215 \mathrm{~g} \mathrm{cod} \mathrm{d}^{-1}$ (Brekke \& Gabrielsen 1994) or $6.44 \mathrm{cod} \mathrm{d}^{-1}$ based on size measurements from Allen Bay (Welch et al. 1993), foraging for $4 \mathrm{~h} \mathrm{~d}^{-1}$ is sufficient to meet energetic requirements.

Glaucous gulls and parasitic jaegers were responsible for the majority of cod stolen from other birds. The glaucous gull was highly efficient, capturing prey from other birds in almost half its attempts. Glaucous gulls were also successful at capturing cod directly but few attempts were made indicating they rely more on other birds. Optimal foraging theory predicts that predators will forage to maximize the net intake of energy (Stephens \& Krebs 1986). Kleptoparasitism appears to be more energetically profitable than capturing cod directly. While the glaucous gull uses its speed and size to steal food, the parasitic jaeger utilizes its aerial-acrobatics skill to harass other birds thereby optimizing its chance of acquiring food. Furness (1987) suggested that a successful stealing rate of 10 to $20 \%$ for parasitic jaegers would be sufficient to sustain food stealing as a foraging strategy. Based on the success rate of 
stealing cod, glaucous gulls and parasitic jaegers are likely able to survive around Allen Bay during the summer without any other foraging method. Not surprisingly, fulmars only lost cod to glaucous gulls while kittiwakes lost many captures to both parasitic jaegers and glaucous gulls. Since fulmars usually remain on the water after captures, parasitic jaegers were unable to use their aerial-acrobatic skill to successfully steal cod. By contrast glaucous gulls efficiently stole cod from birds in air and on water using their speed and size.

\section{CONCLUSION}

This study has provided new information on seabird foraging in relation to a keystone fish species in the Canadian Arctic, but there are some limitations. Initially, non-schooling cod may have been overestimated since schools could have been present but unseen. Further, since observation periods were averaged to ensure independent results, the sample size was reduced. Finally, this was a single-year study and future changes in cod distribution and environmental variables may affect foraging.

To our knowledge, this is the first systematic study to describe and quantify direct observations of feeding interactions distant from breeding colonies in the Canadian High Arctic. Piatt et al. (2007b) considered the most important parameters to study seabirds as indicators are associated with foraging grounds (as opposed to breeding colonies) because most responses depend on prey acquisition from the sea.

Seabirds are typically opportunistic generalists but in Allen Bay showed specialized feeding on cod during the summer. Both schooling and non-schooling cod were important sources of energy for seabirds, which differs from the hypothesis of Welch et al. (1992) that non-schooling fish provide a limited energy source for predators. Kleptoparasitism was a major component of interspecific interactions in this area of the Arctic during the summer and may be somewhat unique. Kleptoparasitism enabled glaucous gulls and parasitic jaegers to obtain up to 8 times more cod compared to direct feeding by fulmars and kittiwakes. Harding et al. (2007) suggested that seabird responses to differing prey availability could be used as indicators of fish distribution. We provided evidence that seabirds are indicators of the marine ecosystem in a nearshore Arctic feeding area.
Acknowledgements. We thank B. Iqaluk from Resolute for assistance in the field, as well as D. Overgaard. We acknowledge M. Mallory of CWS for providing helpful seabird information, advice, and equipment. We also thank K. Gardiner, G. Lipkey, O. Friesen, G. Lescord, N. Bodimeade, and N. Kenkel for advice and support. This research was only possible with use of the Polar Continental Shelf Base and its staff, including Y. Laroche, B. Eckalook, J. MacGregor, M. Kristjanson, as well as the Hunters and Trappers Association in Resolute. A special acknowledgement is dedicated to $\mathrm{M}$. Bergmann for his significant contribution to Arctic research. Funding was provided by the Canadian Foundation for Innovation (CFI) and the Natural Sciences and Engineering Research Council (NSERC) in association with the Ocean Tracking Network (OTN) to T.A.D. and A.T.F.

\section{LITERATURE CITED}

Bélisle M, Giroux JF (1995) Predation and kleptoparasitism by migrating parasitic jaegers. Condor 97:771-781

- Benoit D, Simard Y, Gagné J, Geoffroy M, Fortier L (2010) From polar night to midnight sun: photoperiod, seal predation, and the diel vertical migrations of polar cod (Boreogadus saida) under landfast ice in the Arctic Ocean. Polar Biol 33:1505-1520

Birt-Friesen VL, Montevecchi WA, Cairns DK, Macko SA (1989) Activity-specific metabolic rates of free-living northern gannets and other seabirds. Ecology 70: 357-367

Bradstreet MSW (1976) Summer feeding ecology of seabirds in eastern Lancaster Sound, 1976. Unpubl. report. LGL, Toronto

Bradstreet MSW, Cross WE (1982) Trophic relationships at High Arctic ice edges. Arctic 35:1-12

Bradstreet MSW, Finley KJ, Sekerak AD, Griffiths WB, Evans CR, Fabijan MF, Stallard HE (1986) Aspects of the biology of Arctic cod (Boreogadus saida) and its importance in arctic marine food chains. Can Tech Rep Fish Aquat Sci 1491

Brekke B, Gabrielsen GW (1994) Assimilation efficiency of adult kittiwakes and Brünnich's guillemots fed capelin and Arctic cod. Polar Biol 14:279-284

Bryant DM, Furness RW (1995) Basal metabolic rates of North Atlantic seabirds. Ibis 137:219-226

Carmack EC, Macdonald RW (2002) Oceanography of the Canadian Shelf of the Beaufort Sea: a setting for marine life. Arctic 55(Suppl 1):29-45

Daunt F, Benvenuti S, Harris MP, Dall'Antonia L, Elston DA, Wanless S (2002) Foraging strategies of the black-legged kittiwake Rissa tridactyla at a North Sea colony: evidence for a maximum foraging range. Mar Ecol Prog Ser 245:239-247

Diemer KM, Conroy MJ, Ferguson SH, Hauser DDW, Grgicak-Mannion A, Fisk AT (2010) Marine mammal and seabird summer distribution and abundance in the fjords of northeast Cumberland Sound of Baffin Island, Nunavut, Canada. Polar Biol 34:41-48

Elliott KH, Woo K, Gaston AJ, Benvenuti S, Dall'Antonia L, Davoren GK (2008) Seabird foraging behaviour indicates prey type. Mar Ecol Prog Ser 354:289-303

Fortier M, Fortier L, Hattori H, Saito H, Legendre L (2001) Visual predators and the diel vertical migration of copepods under Arctic sea ice during the midnight sun. J Plankton Res 23:1263-1278 
Furness RW (1987) Kleptoparasitism in seabirds. In: Croxall JP (ed) Seabirds: feeding ecology and role in marine ecosystems. Cambridge University Press, Cambridge, p 77-100

Furness RW, Bryant DM (1996) Effect of wind on field metabolic rates of breeding northern fulmars. Ecology 77 : 1181-1188

Garthe S, Furness RW (2001) Frequent shallow diving by a northern fulmar feeding at Shetland. Waterbirds 24 : 287-289

Giraldeau LA, Caraco T (2000) Social foraging theory. Princeton University Press, Princeton, NJ

Gould PJ, Forsell DJ (1989) Techniques for shipboard surveys of marine birds. Technical Report 25. US Dep Inter Fish Wildl Serv, Washington, DC

Harding AMA, Piatt JF, Schmutz JA (2007) Seabird behavior as an indicator of food supplies: sensitivity across the breeding season. Mar Ecol Prog Ser 352:269-274

Hobson KA (1993) Trophic relationships among high Arctic seabirds: insight from tissue-dependent stable-isotope models. Mar Ecol Prog Ser 95:7-18

Hoffman W, Heinemann D, Wiens JA (1981) The ecology of seabird feeding flocks in Alaska. Auk 98:437-456

Lagadeuc Y, Boulé M, Dodson JJ (1997) Effect of vertical mixing on the vertical distribution of copepods in coastal waters. J Plankton Res 19:1183-1204

Mallory ML, Fontaine AJ (2004) Key marine habitat sites for migratory birds in Nunavut and the Northwest Territories. Occas Pap Can Wildl Serv No. 109. Canadian Ministry of the Environment, Ottawa

Mallory ML, Karnovsky NJ, Gaston AJ, Hobson KA and others (2010) Temporal and spatial patterns in the diet of northern fulmars Fulmarus glacialis in the Canadian High Arctic. Aquat Biol 10:181-191

McKinnon L, Gilchrist HG, Fifield D (2009) A pelagic seabird survey of Arctic and sub-Arctic Canadian waters during fall. Mar Ornithol 37:77-84

Moore AL, Damania SP, Henson SM, Hayward JL (2008) Modeling the daily activities of breeding colonial seabirds: dynamic occupancy patterns in multiple habitat

Editorial responsibility: Rory Wilson, Swansea, UK patches. Math Biosci Eng 5:831-842

Niemi A, Paulic J, Cobb D (2010) Ecosystem status and trends report: Arctic marine ecozones. DFO Can Sci Advis Sec Res Doc 2010/066

Piatt JF, Sydeman WJ, Wiese F (2007a) Introduction: seabirds as indicators of marine ecosystems. Mar Ecol Prog Ser 352:199-204

Piatt JF, Harding AMA, Shultz M, Speckman SG, van Pelt TI, Drew GS, Kettle AB (2007b) Seabirds as indicators of marine food supplies: Cairns revisited. Mar Ecol Prog Ser 352:221-234

Reeves RR, St. Aubin DJ (2001) Belugas and narwhals: application of new technology to whale science in the Arctic. Arctic 54:iii-vi

> Sameoto DD (1984) Vertical distribution of zooplankton biomass and species in northeastern Baffin Bay related to temperature and salinity. Polar Biol 2:213-224

Stempniewicz L, Iliszko L (2010) Glaucous gulls kleptoparasiting Arctic foxes in Magdalenefjorden, NW Spitsbergen. Arctic 63:107-111

Stephens DW, Krebs JR (1986) Foraging theory. Princeton University Press, Princeton, NJ

Tasker ML, Hope Jones P, Dixon T, Blake BF (1984) Counting seabirds at sea from ships: a review of methods employed and suggestion for a standardized approach. Auk 101:567-577

Warham J (1996) The behaviour, population biology and physiology of the petrels. Academic Press, London

Welch HE, Bergmann MA, Siferd TD, Martin KA, Curtis MF, Crawford RE, Conover RJ, Hop H (1992) Energy flow through the marine ecosystem of the Lancaster Sound region, Arctic Canada. Arctic 45:343-357

Welch HE, Crawford RE, Hop H (1993) Occurrence of Arctic cod (Boreogadus saida) schools and their vulnerability to predation in the Canadian High Arctic. Arctic 46: 331-339

> Welcker J, Moe B, Bech C, Fyhn M, Schultner J, Speakman JR, Gabrielsen GW (2010) Evidence for an intrinsic energetic ceiling in free-ranging kittiwakes Rissa tridactyla. J Anim Ecol 79:205-213

Submitted: May 13, 2011; Accepted: December 15, 2011 Proofs received from author(s): March 7, 2012 